NBER WORKING PAPER SERIES

\title{
DO CHILD TAX BENEFITS AFFECT THE WELLBEING OF CHILDREN? EVIDENCE FROM CANADIAN CHILD BENEFIT EXPANSIONS
}

\author{
Kevin Milligan \\ Mark Stabile \\ Working Paper 14624 \\ http://www.nber.org/papers/w14624 \\ NATIONAL BUREAU OF ECONOMIC RESEARCH \\ 1050 Massachusetts Avenue \\ Cambridge, MA 02138 \\ December 2008
}

This research has been supported by a CLSRN grant. We thank Josh Lewis for excellent research assistance. We also thank seminar participants at Alberta, Cornell, McGill, RAND, and Simon Fraser, as well as lunch workshop participants at UBC and several conference participants and discussants for many very helpful suggestions. This paper represents the views of the authors and does not necessarily reflect the views of Statistics Canada. The data used in his article can be obtained through application to Statistics Canada's Research Data Centre program at http://www.statcan.ca/english/rdc/index.htm. The views expressed herein are those of the author(s) and do not necessarily reflect the views of the National Bureau of Economic Research.

NBER working papers are circulated for discussion and comment purposes. They have not been peerreviewed or been subject to the review by the NBER Board of Directors that accompanies official NBER publications.

(C) 2008 by Kevin Milligan and Mark Stabile. All rights reserved. Short sections of text, not to exceed two paragraphs, may be quoted without explicit permission provided that full credit, including $\odot$ notice, is given to the source. 
Do Child Tax Benefits Affect the Wellbeing of Children? Evidence from Canadian Child Benefit Expansions

Kevin Milligan and Mark Stabile

NBER Working Paper No. 14624

December 2008

JEL No. I1,I2

\begin{abstract}
A vast literature has examined the impact of family income on the health and development outcomes of children. One channel through which increased income may operate is an improvement in a family's ability to provide food, shelter, clothing, books, and other expenditure-related inputs to a child's development. In addition to this channel, many scholars have investigated the relationship between income and the psychological wellbeing of the family. By reducing stress and conflict, more income helps to foster an environment more conducive to healthy child development. In this paper, we exploit changes in child benefits in Canada to study these questions. Importantly, our approach allows us to make stronger causal inferences than has been possible with the existing, mostly correlational, evidence. Using variation in child benefits across province, time, and family type, we study outcomes spanning test scores, mental health, physical health, and deprivation measures. The findings suggest that child benefit programs in Canada had significant positive effects on test scores, as has been featured in the existing literature. However, we also find that several measures of both child and maternal mental health and well-being show marked improvement with higher child benefits. We find strong and interesting differences in the effects of benefits by sex of the child: benefits have stronger effects on educational outcomes and physical health for boys, and on mental health outcomes for girls. Our findings also provide some support for the hypothesis that income transfers operate through measures of family emotional well-being.
\end{abstract}

\author{
Kevin Milligan \\ Department of Economics \\ University of British Columbia \\ \#997-1873 East Mall \\ Vancouver, B.C. \\ CANADA V6T1Z1 \\ and NBER \\ kevin.milligan@ubc.ca \\ Mark Stabile \\ School of Public Policy and Governance \\ University of Toronto \\ Canadiana Building, 3rd Floor \\ 14 Queen's Park Cres. W. \\ Toronto, ON M5S 3K9 \\ CANADA \\ and NBER \\ mark.stabile@utoronto.ca
}




\section{Introduction}

A primary tool for addressing child poverty and increasing the chances for children to succeed in school, and subsequently the labor market, is income transfers to families with children. Almost all developed countries either have direct child benefits or target welfare/social assistance benefits at families with children. These benefits are meant to help achieve several goals. First, by investing in children of lesser means, society aims to provide these children with opportunities to be well-adjusted and productive members of society, with improved educational, and later, labor market outcomes. Second, benefit programs allow society to help achieve distributional and equity goals regardless of the future returns of these transfer programs.

Child benefit programs, as well as social assistance programs that target groups such as single parents with young families, transfer income to expand the budget set of qualifying families. There are several potential mechanisms through which this expansion of family budgets may improve outcomes for children. On the one hand, families may simply use the income to purchase more goods and services, including those goods that are valuable in maintaining basic child welfare and also for enhanced child development (food, clothing, books, etc). On the other hand, income transfers may have indirect effects such as reducing stress and improving household relations, increasing the chance and opportunities for employment, and others, which, while not goods and services purchased with the extra income, may benefit family members, including children, and therefore improve their ability to function, learn, and improve themselves. 
These two channels are explored in Mayer (1997) and Yeung et al (2002), among others, and we borrow terminology from the previous literature here. Direct purchases of resources useful for child development is called the 'resources' channel. Improved family relations and emotional well-being is called the 'family process' channel. While the majority of the economic literature has focused on the resources channel, our paper instead examines the effects of benefit programs on a wide range of child outcomes which fall naturally under the family process channel. Recent research (Currie and Stabile, 2008; Currie, Stabile, Manivong and Roos, 2008) has documented a strong relationship between early child mental health and not only short term educational achievement, but longer-term economic outcomes such as welfare take-up.

The paper offers two main contributions to the previous work in this area. First, it uses an exogenous source of child benefit income based solely on legislative variation rather than the observed income or other choices made by the family. Second, it uses a detailed Canadian survey of child well-being that includes several important outcomes of interest spanning test scores, mental health, physical health, and poverty measures. This survey allows a more rigorous examination of the family process channel than has been explored in previous work.

Our findings suggest that child benefit programs in Canada had significant positive effects on several measures of both child and maternal mental health and well-being, as well as a few measures of child physical health. Our findings provide some support for the hypothesis that income transfers operate through the family process channel, specifically through measures of emotional well-being and development. We find less evidence of direct effects of child benefits on test scores. Interestingly, we find strong differences in 
the outcomes improved by child benefits by the sex of the child. For boys, benefits have much stronger effects on educational outcomes and physical health measures. For girls, benefits have much stronger effects on mental health measures. These differences suggest that the channels through which benefits improve outcomes may be multiple and may differ by gender.

\section{Previous work}

There is an extensive literature on the broader relationship between income and child health and development. ${ }^{1}$ Several difficulties make the study of this relationship complex, including measuring income, distinguishing between permanent or transitory effects, finding exogenous ways to measure income, capturing the effects of other inputs into this production relationship, and finding the proper outcomes to capture the potential effects. Further, documenting a relationship between family income and child outcomes does not in itself help us understand through which channels income works in order to achieve any measured effects. Mayer (1997) provides a thorough treatment of the sociological theory and developed new empirical evidence based on the NLSY, finding that income was not a strong determinant of long-run outcomes. Blau (1999) presents a discussion of these issues from an economist's perspective and reviews much of the previous literature that does not deal directly with the issue of the endogeneity of income. Using fixed effects models and the NLSY, Blau concludes that the effects of permanent family income on test scores are small compared to other family and child characteristics,

\footnotetext{
${ }^{1}$ See an extensive review of the literature of the determinants of child wellbeing in Haveman and Wolfe (1995).
} 
leaving income transfers as a poor policy tool to improve the outcomes of low-income children.

On the other hand, a more recent study by Dahl and Lochner (2005), also using the NLSY, finds reasonably substantial effects of income on child test scores. Dahl and Lochner use changes in the earned income tax credit over several years to exogenously identify income through fixed-effect IV models. This identification strategy relies on federal changes in the benefit structure of the EITC and the tax code over time as well as changes in labor market returns to exogenous maternal characteristics over the same time period, primarily education. A key identifying assumption for this strategy, then, is that the educational changes over time are not correlated with other temporal changes that might also affect the outcomes in question. They also restrict their attention to test scores.

A study in the child development literature by Yeung, Linver, and Brooks-Gunn (2002) focuses on understanding the channels through which family income matters for child development. The authors hypothesize and test the two channels discussed earlier in the introduction, being resources and family process. The authors use the Panel Study of Income Dynamics to test these two perspectives. They find stronger evidence in support of the second hypothesis than the first although these results are primarily based on direct OLS estimates of this relationship including a wide variety of explanatory variables. So, while suggestive, it is difficult to draw causal inferences from this evidence.

In a Canadian study using the National Longitudinal Survey of Children and Youth, Dooley and Stewart (2004) use a variety of OLS and fixed-effects models to estimate the relationship between family income and test sores. The results from these models are similar to those found in Blau (1999) in that they find a small relationship between income 
and test scores. They also find some limited impact of the consumption channel through measures of children's activities (day camps, sports, etc.) and housing amenities.

Our work builds on this literature in a variety of ways. First, we exploit variation over time, across provinces, and across number of children, to develop an exogenous measure of benefit income as an instrument for child benefits. Second, we are able to examine a variety of outcomes, including test scores, but also including a variety of physical and mental health measures. As a result we are able to provide an exogenous estimate of the effects of benefit income on a variety of potential pathways for child development, and on a standard set of test score measures to capture child outcomes.

\section{Policy}

The Canadian child benefit system consists of two main benefits. First, the Canada Child Tax Benefit (CCTB) is paid to parents of children age 0 to 17 . This is a federal benefit initiated in 1993 that pays the same across the country with two small exceptions. ${ }^{2}$ The CCTB is payable for a twelve-month period running from July to June, with the amount dependent upon the reported net income of the parents in the previous calendar year. ${ }^{3}$ So, the July 2005 to June 2006 maximum annual benefit of $\$ 1,228$ per child was reduced based on reported family net income from 2004. Benefits do not depend on earned income specifically, so families with no income still qualify for the benefit. Take-up is high -in many provinces the application is given to families of newborns and the

\footnotetext{
${ }^{2}$ In Alberta, the benefit is differentiated by age of the child. For example, in 2005 children age zero to six received $\$ 1,124$ while those age 16 to 17 received \$1,423. Until 1997, benefits paid to Quebec residents depended on how many children were in the family, with higher-order children receiving more benefits. ${ }^{3}$ For 2005 , the clawback threshold is $\$ 36,378$, with a reduction rate of 2.5 percent for income over that threshold for one-child families, and 5 percent for two or more child families.
} 
administration is well-integrated with the tax system so any tax filer who qualifies will be made aware of the transfer. The benefit level was constant in nominal dollars between 1993 and 1999, but has been indexed to CPI inflation since 2000. A small supplement (\$86 annually in 2005) is available for a third or higher order child, and another supplement (\$243 annually in 2005) was available until 2006 for children age zero to six for those not claiming childcare expenses.

The second component of the child benefit system is the National Child Benefit program, begun in 1998. This program is a federal-provincial initiative that features a federally-paid benefit called the National Child Benefit Supplement (NCBS). Provinces, at their discretion, could subtract the NCBS from welfare recipients in their province and use the 'savings' to fund different provincial programs and child benefits. This yielded substantial differences in benefits across provinces. In addition, the province of Quebec, while it elected to stay outside the NCB program, instituted major reforms of its child benefits system in 1997 and 2005. The details of each province's programs are provided in the Appendix. In short, two provinces introduced new transfers that weren't related to earnings, two provinces introduced earnings-related benefits, and three provinces did both. Across provinces, there were large differences in the structure of benefits across family size.

The net impact of these changes is a large degree of heterogeneity in child benefits across several dimensions: year, province, number of children, and income. There is no explicit dependence of benefits on marital status or education, but benefit levels across those dimensions will vary through differences in family income. Because our empirical strategy will attempt to exploit only the exogenous components of policy variation, we 
concentrate primarily on three dimensions of heterogeneity (year, province, number of children).

In Figure 1 we trace out the average benefits payable across time and for different numbers of children in each province. The main differences stem from the 1998 introduction of the NCB program and its provincial counterparts. Some provinces, such as $\mathrm{BC}$ moved a bit earlier. Other provinces, like Prince Edward Island, had no benefit program and so had no province-specific variation. Across other provinces, the biggest differences that can be seen are for the three-child families compared to the one child families. We provide some more information on benefit levels later in Table 1.

\section{Empirical Strategy}

The crucial empirical challenge for estimating the impact of child benefits on outcomes is unobserved heterogeneity. The solution we employ extracts plausibly exogenous legislative variation in benefits to remove the bias of unobserved correlates of child outcomes. In particular, we use a simulated benefits approach similar to that in Currie and Gruber (1996). The method involves taking a sample of families and pushing them through a tax and benefit simulator 400 times - once for each of the ten provinces, each of the ten years between 1994 and 2003, and of four family sizes $(0,1,2$, or 3 children). We then take the average benefit level for each of these cells. The resulting benefit levels differ across time periods, years, and family sizes only through differences in legislated benefit levels and not by income or any unobservables that may be correlated with income.

To calculate the benefits, we select a ten percent sample of families with children from the Survey of Labour and Income Dynamics (described in more detail later) between 
the years 1999 and 2004. These families are stripped of everything except for marital status and incomes - they are essentially providing nothing more than a reasonable distribution of incomes to use for the simulation. The tax and benefit simulator we employ is the CTaCS package, which is described in detail in Milligan (2007). Importantly, the child benefits components of the calculator were developed by looking directly at the legislation and regulations for each province and coding these parameters and program rules into the calculator. After putting these families through the calculator, we take the mean of the simulated child benefits by province-year-number of children cell.

We take these simulated benefits and estimate first-stage equations of the following type:

$$
B E N_{p y k i}=\beta_{0}+\beta_{1} X_{p y k i}+\beta_{2} \operatorname{SIMBEN}_{p y k}+\varepsilon_{p y k i} .
$$

The indexes on the variables represent provinces $(\mathrm{p})$, years $(\mathrm{y})$, number of children (k), and families (i). The reported child benefit levels $B E N_{p y k i}$ are predicted by the set of observable characteristics $X_{p y k i}$ and the simulated benefit level $S I M B E N_{p y k}$. We include not only the main effects of province, years, and number of children, but also the $2^{\text {nd }}$ order interactions of these three factors.

The predicted values from our first-stage can then be used in a second-stage regression using child outcomes, taking the following form:

$$
\text { Outcome }_{p y k i}=\alpha_{0}+\alpha_{1} X_{p y k i}+\alpha_{2} \overline{B E N_{p y k i}}+\eta_{p y k i} \text {. }
$$

The predicted value of the child benefit $\overline{B E N_{p y k i}}$ is used to explain various child outcome measures Outcome $_{p y k i}$. We include the same $X_{p y k i}$ characteristics in the second stage regression including all second order interactions. In this way, the identification of the impact of child benefits comes through the exclusion of the fully saturated third order interactions of the province, year, and number of children effects. So long as the simulated 
benefit measure is a good (even if not perfect) predictor of actual benefits and so long as there are no confounding province-year-number of children trends or policies that invalidate the exclusion restriction, the simulated benefit represents a valid instrument. For reasons made clear later, most of our results use a reduced form specification, which involves inserting the simulated benefit measure directly in the outcome variable regression. However, we do report some results using the full two-stage procedure.

An important challenge to this identification strategy might come from other policy reforms contemporaneous with the changes in child benefits. For example, provincial spending programs introduced as part of the NCB program could have influenced child welfare. Similarly, other policy reforms such as the subsidized childcare program in Quebec studied in Baker, Gruber, and Milligan (2008) might affect the environment. However, our inclusion of province by year effects adequately controls for most of these concerns. That is, any impact of new provincial spending programs will be picked up by the province-year dummies as there is no reason to expect them to have differentially impacted families with different numbers of children. To our knowledge, the income benefits are the only aspect of the program that is differentiated by the number of children.

Another problem could arise from different labor market cycles across provinces. However, because our identification relies on differences across families of different sizes, this problem only affects our strategy if province-year labor market shocks had a differential impact on families with one versus two versus three children.

\section{Data}

We use two data sources for the study. Our primary source for data is the National Longitudinal Study of Children and Youth (NLSCY). This survey focuses on Canadian 
children, with data currently available for six biannual waves spanning 1994-95 to 2004-05. The content of the survey combines extensive parent-reported health, well-being, and developmental information on the child and family with detailed labor market and income information for the parents. The survey initially covered children aged 0 to 11 in wave 1 and has followed that initial cohort to ages 10 to 21 in wave 6 . Young children were added in each wave to fill in the gap, allowing cross-sectional coverage of all ages. ${ }^{4}$

We use all families in each of the NLSCY waves with children ages 10 and under. The resulting data set comprises approximately 56,000 observations over six cycles. However, for many of the outcomes we examine, the variables are limited to explicit age ranges, making the sample sizes for the analysis considerably smaller that the full data set. Finally, because there is some over-sampling of children in smaller provinces, we use the provided weights to recover population-level results.

The NLSCY contains several variables spanning achievement measures, physical, and mental health including having repeated a grade, a math score, a PPVT score, having been diagnosed with a learning disability, measures of hyperactivity, emotional and anxiety disorders, physical aggression, suffering from hunger, height and weight, and mother's health status. Means and age ranges for the variables presented in each of the results tables.

Questions are asked of the person most knowledgeable about the child (in $92 \%$ of cases this is the mother) about whether the child repeated a grade in past two years. The Peabody Picture Vocabulary Test is administered to children ages 4-6 and is a widely used measure of cognition for preschoolers. In the NLSCY, mathematics tests were administered to children in grades two through ten (beyond the age limits of our sample) and are based

\footnotetext{
${ }^{4}$ For wave 5, cross-sectional child observations were only added in the age range $0-5$. Because the longitudinal cohort was ages 8-19 in wave 5, this left an unfilled gap at ages 6-7for wave 5. Similarly, there is an age gap in the range 6 to 9 for wave 6 .
} 
on the Canadian Achievement Tests. Response rates for the Math tests are slightly low and various researchers have investigated how these low response rates might bias analysis using the test $\operatorname{scores}^{5}$ and have concluded that the low response is random, for the most part. The question on learning disabilities asks about whether the child has been diagnosed and is answered by the person most knowledgeable about the child. The questions on mental and emotional health are asked of parents of all children aged 4 through 11 (we list the questions in the data appendix). The responses to these questions are categorized by disorder, and then added together to determine a hyperactivity score (8 questions), an emotional behavior score (8 questions), an aggressive behavior score (6 questions) an indirect aggression score (5 questions), and a prosocial behavior score (10 questions) for the child. The mother's depression score is again based on a series of twelve questions asked to the child's mother about her feelings and behavior over the past week.

The child and mother health questions are self-reported based on a 5 point scale for self-assessed health of excellent to poor. We combine the bottom three measures for the child as very few parents report their child to be in poor health. Height and weight measures are also self-reported by the parent as are measures of injuries in the past twelve months, and reports of the child experiencing hunger because of lack of resources to buy food.

Parent reports about their children are sometimes thought less reliable. Parents may hold a more optimistic opinion of their child's abilities and activities than a disinterested observer. Beyond any bias in their true assessments, parents might also be reluctant to

\footnotetext{
${ }^{5}$ In cycle 5 the response rate for the mathematics test was $81 \%$. Currie and Stabile (2006) discuss an analysis of the non-responses to the NLSCY math tests for previous cycles performed by Statistics Canada which reports little difference between responders and non-responders at that time. In the cycle 5 codebook, Statistics Canada notes that the response rate is lower in higher grades, and higher among students who performed well on previous cycle math tests.
} 
report low achievements out of shame or embarrassment. On the other hand, differences in parent versus expert reports may lie in differences in information-parents may be better informed and thus make more accurate reports. Evidence suggests that parent reports can be reliable in the spheres of motor milestones (Bodnarchuk and Eaton 2004), child health (Spencer and Coe 1996), and behavior and temperament (Clarke-Stewart et al. 2000). However, the validity of the particular measures in the NLSCY may differ from the measures in those studies. A common finding in the literature on validity of parent-reported measures is that the validity of parent-reports for acute events (such as an illness or the reaching of a milestone) is higher than for more general and broad questions. ${ }^{6}$

The other survey we use is the Survey of Labour and Income Dynamics (SLID), stacking together the public-use cross sections for the years 1996 to 2004 . We use this survey both to populate our simulation sample used to generate the simulated child benefits and also for validation of the predictive power of the simulated benefits. The SLID is conducted annually by Statistics Canada with a stratified random sampling of Canadians. With survey weights, the data are potentially nationally representative. The SLID provides detailed information on demographics, and more precise information on income and benefits received over the past year than the NLSCY which allows us to provide more complete income and benefit information to the tax calculator. In particular, the income measures available on the SLID are attached from the respondent's income tax records, which makes them quite relevant for the tax calculator. The sample size per year is around 35 thousand census families made up of 60 thousand individuals aged 15 and higher.

\footnotetext{
${ }^{6}$ Baker, Gruber, and Milligan (2008) have an extensive discussion of the measures in the NLSCY in their Appendix B.
} 


\section{Results}

The first set of results we present shows the mean benefit levels federally, provincially, and in total. We next explore the first stage relationship between our simulated child benefits and actual reported child benefits. Following the discussion of the first stage results, we turn to our analysis of child and family outcomes from the NLSCY. Our main specifications use the predicted benefits in reduced form regressions, for reasons made clear below. We consider the entire sample of children, as well as samples by sex of the child and also present results for children of mothers with lower levels of education, as these families are more likely to be eligible for child benefits ( as shown below). We show our analysis in three groups of outcome variables: education, mental and emotional wellbeing, and health and nutrition. We then present some results that exploit the panel features of the NLSCY, looking at the persistence of any effects through time. Finally, we present specification checks that instrument for actual benefits using the predicted benefits as well as uses alternate sub-samples ${ }^{7}$.

For all continuous variables, we have normalized the variables using the mean and standard deviation, so that the coefficients can be interpreted in terms of changes in standard deviations. The key independent variable is the dollar value of child benefits, expressed in thousands of dollars. All dollar values in the paper are transformed to 2004 constant dollars.

\section{Benefit levels}

Table 1 presents the mean and standard deviation of benefit levels at the federal and provincial level, as well as the total. We show the results across all observations and

\footnotetext{
${ }^{7}$ The models estimates here all include multiple children from the same household due to the sampling in the NLSCY. We have re-estimated all the models using only a single child from each family and find very similar results with little change in the P-values.
} 
broken down by mother's education. This is important to understand where our variation is coming from and to motivate our sample choices and robustness checks. The data used for this table is the 2004 SLID for families with a child under or at age 10, with all results in 2004 dollars.

The first row indicates that 85 percent of Canadian families receive some child benefits, with an average amount of $\$ 2,174$ - this includes those with zero in the average. Not shown in the table, a breakdown by income shows that the proportion of families with income under $\$ 60,000$ receiving some child benefits is almost 1 -in the SLID takeup appears close to universal. Only 28.8 percent of families receive any provincial benefits, reflecting both more narrow income targeting and also that several provinces have no provincial benefit. The average benefit is only $\$ 222$, but among those receiving any benefit it is $\$ 769$.

The last four rows break down the sample into groups by maternal highest level of education. For high school graduates and drop-outs, over 90 percent are receiving benefits. This reflects low income levels for these families, not an education-related takeup rate. While the proportion receiving benefits remains relatively high across all education groups, the average benefit does decline sharply, reflecting the phase out of benefits at higher income levels. The provincial benefits are positive for only 14.6 percent of families, with a much lower average amount. This is important because our identifying variation comes not from province (and family size) level variation. For higher education families, the provincial benefits are not sizeable.

$\underline{\text { First stage results }}$ 
We begin with an analysis of the relationship between our simulated child benefits and actual reported child benefits. This analysis allows us to validate the use of the simulated benefits in reduced form regressions (where we look for the direct effect of the simulated benefits on outcomes). These first stage results are performed using the person files of the SLID for the years 1996 to 2004. The SLID includes a much larger sample than the NLSCY, is specifically designed as an income survey, and can be applied to all of the years over our time span of interest. These three reasons make it a preferable data source for validation and estimation of our first-stage relationship.

The results appear in Table 2. Each result in the table comes from a separate regression of reported child benefits on simulated benefits with a set of standard control variables. $^{8}$ A clustered standard error is reported beneath in parentheses. The different rows of the table show results from different subsamples of the SLID data. The columns show results using different formulations of the policy variable. The first column shows results using a difference-in-differences specification that exploits only province-year variation. The second column uses a triple-difference specification with simulated benefits varying on a province-year-number of children basis. The third column is also a triple difference specification, but uses a measure of child benefits that adjusts for the reduction of welfare benefits resulting from the NCB clawback. That is, it accounts for the net change in income. ${ }^{9}$

The first result is a regression using only families with a child age 0 to 17 , which captures any families potentially eligible for child benefits. The reported coefficient of 941 indicates that an extra $\$ 1000$ of simulated benefits is predicted to increase reported child

\footnotetext{
${ }^{8}$ The controls include year dummies, province dummies, number of children dummies, respondent and spouse education and age group dummies, a marital status indicator, and age of youngest child dummies. ${ }^{9}$ For these simulations, families in the simulation sample who had social assistance income and were in a 'clawback' province had their benefit level adjusted to account for the clawback. See Milligan and Stabile (2007) for details on the clawback.
} 
benefits by $\$ 941$. The result is highly significant and indicates that the simulated benefits are a very precise and accurate predictor of reported child benefits. The coefficient is littlechanged in the triple difference specifications in columns two and three. The next row restricts the sample to children age 0 to 10 , which is the age range we use for the NLSCY analysis to follow. In this sample, the province-year specification shows an increase in actual benefits of $\$ 1,354$ for every $\$ 1,000$ of simulated benefits. In the second and third columns, the estimated coefficient falls back under $\$ 1,000$. In the subsample containing only those observations where the respondent has high school education or less, the point estimates in the triple-difference specifications are slightly lower at $\$ 860$ and $\$ 868$, but remain highly significant. In the sample containing only two-parent families, the results look very similar to the base age 0 to 10 results in the second row. In contrast, the results in the sample of single parents show coefficients more than twice as high, indicating that simulated benefits substantially underpredict actual benefits. This may be driven by the fact that single-parent families have lower family income and therefore get more benefits than two-parent families. Because of the preponderance of two-parent families in the whole sample, the province-year-number of children cell averages for the simulated benefits are dominated by the two-parent families.

Overall, the analysis of the first stage in the SLID allows for firm confidence that the simulated benefits are good predictors of actual benefits. Because the coefficients are in most specifications relatively close to $\$ 1$ for $\$ 1$, reduced form estimates using the simulated benefits will yield results very similar to two-stage estimates using these results as a first stage. This diminishes the motivation for using an IV estimator over the reduced form specification. As a result we focus our analysis on the reduced form results using predicted benefits, although estimates using IV are presented for comparison. 


\section{Educational Outcomes}

Table 3 contains the results for education outcomes. For each dependent variable, we report the number of observations, the age range covered by the variable, the mean and standard deviation, and finally the coefficient on the benefit variable in four different specifications. The number of observations varies primarily because of differing age ranges for the dependent variables. For example, the PPVT scores are available only for children between ages 4 and 6 .

The first row reports whether the child has ever repeated a grade. In the full sample, the significant coefficient of 0.013 suggests that an increase of $\$ 1,000$ in simulated benefits leads to a 1.3 percentage point increase in the probability of having repeated a grade. This result does not persist in the lower education sample including both sexes, and for the lower education sample broken down by sex. This leaves the result inconclusive.

The math and PPVT scores show a positive, but insignificant, relationship between benefits and test outcomes for the entire sample. However, the results in the low education sample show positive and significant relationships in both scores. For the math score, the coefficient is 0.074 , indicating an increase of 7.4 percent of a standard deviation for an increase in $\$ 1,000$ of benefits. The PPVT score yields a similar increase of 6.8 percent of a standard deviation. When compared to other results in the literature finding in the range of 25 percent of a standard deviation for ten thousand dollars more income, the effect observable here is relatively large. When the lower education sample is broken down by sex we find that the result is being driven by boys where the coefficients more than double. The effect for girls, on the other hand, is negative and insignificant. 
The final row of Table 3 displays the result for a binary variable describing whether the child has been diagnosed with a learning disability, as answered by the parent. The mean of this variable is 0.969 , reflecting the fact that very few children have been diagnosed with a learning disability. The estimated coefficient in the full sample is not statistically distinguishable from zero, but in the high school or less sample the estimated coefficient is a significant 1.5 percentage points. Once again, once the sample is broken down by sex we see that this result is driven by boys with a significant coefficient of 2.3 percentage points, and a small and insignificant coefficient for girls.

Overall, the evidence shows some positive impact on educational outcomes. These results appear to be concentrated among boys of families from lower education households (as measured by the educational status of mother). However, since the full sample includes many families who were not recipients of child benefits, we would expect any impact to be diluted. So, the stronger effects in the lower education sample are consistent with expectations.

\section{Mental and Emotional Wellbeing}

We now turn to indicators of mental and emotional wellbeing. Recent literature has highlighted the importance of early mental health problems for long-term educational and labour market success (Currie et al, 2008). These dependent variables take the form of scores, aggregated up from responses to individual questions. We report the questions from the questionnaire in the appendix. These scores have been developed in accordance with established practices in developmental psychology. Baker, Gruber, and Milligan (2008)

provide some detail on studies of the validity of these measures. For the regressions, we have again scaled the variables by the mean and standard deviation so that coefficients 
estimates reflect the proportion of a standard deviation resulting from a $\$ 1,000$ change in benefits.

The first row of Table 4 shows the results for the hyperactivity-inattention score. There are negative coefficients of -0.03 and -0.044 in the full and low education samples, respectively. While the coefficient in the low education sample is larger, the standard error grows by even more, rendering the estimate insignificant. The second row of the table studies the pro-social behavior score. As can be seen in the appendix, these questions reflect how much the child helps other children. The coefficients here are negative, with significance in two out of the four columns. The coefficient in the high school or less sample specification is -0.082 , which is relatively large, and even larger for girls in the sample. These results indicate that the behavior of children deteriorated with respect to helping other children when child benefits increased.

For emotional disorder-anxiety, the point estimates are uniformly negative, but not statistically significant providing little evidence of an effect here.

The next row shows the results for conduct disorder-physical aggression, measuring violent acts towards others. The impact with the full sample is negative and statistically significant and is practically identical for the sample from lower education households. Once again, when we break the sample down by education it appears that this result is driven by the girls in the sample. The final outcome for the child's emotional wellbeing is the indirect aggression score, which measures social rather than violent conflict with other children. The results here show little significance except for the girls in the lower education sample.

We close this analysis with an examination of the depression score of the mother. The depression questions are asked of the person most knowledgeable, so to keep the 
responses consistent we selected only the mothers who were the respondent. The results for this dependent variable are negative and very strong, indicating a significant improvement on maternal depression of increased child benefits. The coefficient on simulated benefits in the reduced form model is -0.116 , which suggests a decrease of 11.6 percent of a standard deviation with a $\$ 1,000$ increase in benefits.

To summarize, several indicators of emotional and behavioral wellbeing indicate that increased child benefits improve the outcomes of children and their mothers. The results are particularly strong for physical aggression and for maternal depression. Prosocial behavior, on the other hand, appears to get worse. Unlike the test score results where it appears that the effects are strongest for the boys from lower education households, the effects on mental well-being are concentrated among girls from lower education households in three of the five measures of mental health, and among the mothers of girls from lower education families for our measure of maternal mental health.

\section{Health and Nutrition}

The final set of variables we analyze looks at the health outcomes of children and their mothers. These results are reported in Table 5, following the same format as the previous two tables. In the first row is a dummy variable for never having experienced hunger. The mean of this variable is 0.987 , reflecting the fact that very few children in the NLSCY have ever experienced hunger. The results in the full sample show no change in this variable when simulated benefits increase, but in the low education sample the coefficient is 0.011 , indicating a small improvement. In this case the result is much stronger among boys than girls. 
Parent assessments of the child's general health level show no change in the reduced form specifications for both sexes together, but show a negative results for boys only (for this variable, the positive coefficients indicate a worsening of health). For height and weight, there are a few significant results but not overwhelming evidence of a large effect here. There is no significant change in injuries sustained over the previous 12 months or in maternal health indicators.

Overall, the health results show some indication that hunger is reduced, but this appears to have little impact on the general health of the child, although there is some improvement in height but not weight. For the subsample of just boys from lower education household, the effects are much more pronounced with an increase in the number of boys who never experience hunger and improved height and overall health status.

\section{Persistence and lags of effects}

While we observe some immediate effects of benefit income on both educational and health related outcomes, there may also be lags and persistence to the effects of income. Some benefits may require time to emerge. Others may drop off over a few years, suggesting that the effect of benefits on long-term outcomes would be more limited. To study the persistence/lags of the estimated impacts of child benefits, we regressed several of the measures found in the previous tables on lags of the benefit measures by exploiting the panel nature of the NLSCY. Specifically, we use the 1997 values of the dependent variables and the 1993 and 1995 benefit measures. For this exercise, we use only the full sample to maximize sample size as the NLSCY panel is considerably smaller than the complete survey. 
The results appear in Table 6 . The coefficients reported in the full sample with only 1993 benefits are in the fourth column of the table. Here, both the math and the PPVT scores show magnitudes very similar to what was uncovered in the contemporaneous analysis in Table 3. This suggests that, over a four year period, the impact of child benefits is similar to the contemporaneous impact. In the last two columns we include both the 1993 and 1995 benefits in the same model. Here, for the math score it is the 1993 benefits that have the larger impact, with no additional gain for the 1995 benefits. In contrast, for the PPVT score, the impact of the 1993 benefits is estimated to be 14.4 percent of a standard deviation, but 10.6 percentage points of this is taken away if 1995 benefits increase. Taken together, this evidence suggests that the impact of child benefits on test scores is persistent.

The next three rows show the results from a selection of the behavioral scores. The hyperactivity result is negative and persistent when looking at the effect of 1993 benefits on the 1997 outcomes, even when controlling for the 1995 benefit level. For aggression, there is a positive impact of lagged benefits when only 1993 benefits are included, but a mixed result when both 1993 and 1995 are included. The maternal depression score shows a negative and significant impact when the 1993 benefit levels are related to the 1997 depression scores. The impacts here remain strong and significant.

Finally, we look at the persistence of the hunger measure. The estimated impacts are positive, and significant for the 1993 benefits. The magnitudes here, however, are small.

\section{Specification Checks:}


Table 7 presents two specification checks for our analysis. The first check uses the simulated benefit as an instrument for actual reported benefits where the first stage is also performed using the NLSCY data (and not the SLID as reported in Table 2). The results are presented in the second column, with the reduced form results in the first column for reference purposes. The first stage fit is weaker in the NLSCY, likely reflecting the fact that this survey has weaker income data than the SLID. However, we continue to get strongly significant predictions, with $\$ 1000$ of simulated benefits predicting $\$ 327$ of actual child benefits. The IV results are considerably different from the reduced form results. While most coefficients have similar signs, only a handful has similar levels of statistical significance. Further, the IV results are considerably larger than the OLS results. This may be a function of measurement error, or a somewhat poorer fit of the first stage in the NLSCY. Nonetheless, some results are consistent with the reduced form results including not being diagnosed with a learning disability, the mother's depression score, and height.

The second specification check examines the effects of child benefits on the population least likely to receive benefits and least likely to benefit from the income children of university graduates. We expect that among this sub-sample, our results should be much weaker. While there still may be examples of university graduates who receive child benefits, the impact should be substantially reduced if we are estimating the true effect of the child benefits on outcomes. Our findings confirm this hypothesis. While we do find a few positive effects of the benefits (on hyperactivity, mother's depression and mother's health status) we find many fewer and smaller effects in this sub-sample, providing us with some additional comfort about our main findings. 


\section{Conclusions}

In this paper, we study the impact of child benefits on measures of education, emotional and behavioral wellbeing, and health. We find indications that increased child benefits led to improved test scores, decreased aggression and maternal depression, and a reduction in hunger. We test for the persistence (or lagged impact) of child benefits and find that the effects of benefits on educational outcomes and emotional well-being of children persist four years after the benefit income was received. Our empirical approach based on exogenous policy changes makes us more confident these results are causal than has been possible with the existing, mostly correlational, literature.

A particularly striking finding in our results is the large difference between the effects of benefit income on boys versus girls. Further, these differences depend on the type of outcome being examined, although they are quite consistent within type of outcome (various health measures versus various education measures). On many of our education and physical health measures we find considerably larger effects for boys. For many of our mental health variables we find considerably larger effects for girls. Finding such differences between sexes is consistent with evidence from other studies examining the impact of various programs on children of various ages (see, for example, Angrist et al (2006), Dynarski 2005 for differences at the college level, and Anderson (2006) for differences at the pre-school level.

Most of the economics research on child benefits has focused on the labor market, educational, and direct-consumption aspects of increased child benefits. We take our findings as evidence that a broader set of outcomes should be included in any assessment of the costs and benefits of expanded transfer payments to families with children. 


\section{References}

Anderson, Michael (2006) "Uncovering Gender Differences in the Effects of Early Intervention: A Reevaluation of the Abecedarian, Perry Preschool, and Early Training Projects," MIT Department of Economics, Ph.D. Thesis.

Angrist, Josh, Lang, Daniel, and Phil Oreopoulos (2006), "Lead them to Water and Pay them to Drink: An experiment with services and incentives for college achievement.” NBER Working Paper 12790.

Baker, Michael, Jonathan Gruber, and Kevin Milligan (2008), "Universal Childcare, Maternal Labor Supply, and Family Well-being," Journal of Political Economy, Vol. 116, No. 4, pp. 709-745.

Blau, David M. (1999), "The effect of income on child development," The Review of Income and Statistics, Vol. 81, No. 2, pp. 261-276.

Bodnarchuk, J.L. and W.O. Eaton (2004), “Can Parent Reports be Trusted?” Journal of Applied Developmental Psychology, Vol. 25, No. 4, pp. 481-490.

Clarke-Stewart, K.A., Fitzpatrick, M.J., Allhusen, V.D. and Goldberg, W.A., (2000), "Measuring difficult temperament the easy way," Journal of Developmental and

Behavioral Pediatrics Vol. 21, No. 3, pp. 207-220.

Currie, Janet and Jonathan Gruber (1996), "Health insurance eligibility, utilization of medical care, and child health," Quarterly Journal of Economics, Vol. 111, No. 2, pp. 431-466.

Currie, Janet and Mark Stabile (2006), "Child Mental Health and Human Capital Accumulation: The Case of ADHD," Journal of Health Economics, Vol. 25, No. 6, pp. 1094-1118.

Currie, Janet and Mark Stabile (2008), "Mental Health in Childhood and Human Capital," forthcoming in An Economic Perspective on the Problems of Disadvantaged Youth, Jonathan Gruber (ed.) (Chicago: University of Chicago for NBER).

Currie, Janet, Stabile, Mark, Manivong, Phongsack and Leslie L Roos, (2008) “Child Health and Young Adult Outcomes" NBER Working Paper No. 14482.

Dahl, Gordon B. and Lance Lochner.(2005), “The Impact of Family Income on Child Achievement," NBER Working Paper No. 11,279.

Dooley, Martin and Jennifer Stewart (2004), "Family income and child outcomes in Canada," Canadian Journal of Economics, Vol. 37, No. 4, pp. 898-917. 
Dynarski, Susan (2005), "Building the Stock of College-Educated Labor," NBER Working Paper no. 11604.

Haveman, Robert and Barbara Wolfe (1995), “The Determinants of Children's Attainments: A Review of Methods and Findings," Journal of Economic Literature, Vol. 33, No. 4, pp. 1829-1878.

Mayer, Susan E. (1997), What Money Can't Buy. Cambridge MA and London: Harvard University Press.

Milligan, Kevin (2007), Canadian Tax and Credit Simulator. Database, software and documentation, Version 2007-2.

Milligan, Kevin and Mark Stabile (2007), "The integration of child tax credits and welfare: Evidence from the Canadian National Child Benefit program," Journal of Public Economics, Vol. 91, No. 1-2, pp. 305-326.

Seifer, R., Sameroff, A. J Dickstein S., Schiller M., L.C. Hayden (2004), "Your own children are special: clues to the sources of reporting bias in temperament assessments" Infant Behavior and Development, Vol. 27, No. 3, pp. 323-341.

Spencer N.J. and C. Coe (1996), "The development and validation of a measure of parent-reported child health and morbidity: the Warwick Child Health and Morbidity Profile," Child: Care, Health and Development, Vol. 22, No. 6, pp. 367-379.

Yeung, W. Jean, Miriam Linver, and Jeanne Brooks-Gunn (2002), "How Money Matters for Young Children's Development: Parental Investment and Family Processes," Child Development, Vol. 73, No. 6, pp. 1861-1879. 


\section{Table 1: Benefit levels by education group}

\begin{tabular}{|c|c|c|c|c|c|c|c|}
\hline & & \multicolumn{2}{|c|}{ Federal Benefits } & \multicolumn{2}{|c|}{ Provincial benefits } & \multicolumn{2}{|c|}{ Total benefits } \\
\hline All observations & $\frac{\text { Observations }}{5134}$ & $\begin{array}{c}\text { Greater } \\
\text { than zero } \\
0.850 \\
(0.357)\end{array}$ & $\begin{array}{c}\text { Amount } \\
2174 \\
(2418)\end{array}$ & $\begin{array}{c}\begin{array}{c}\text { Greater } \\
\text { than zero }\end{array} \\
\begin{array}{c}0.288 \\
(0.453)\end{array}\end{array}$ & $\begin{array}{c}\text { Amount } \\
222 \\
(556)\end{array}$ & $\begin{array}{c}\begin{array}{c}\text { Greater } \\
\text { than zero }\end{array} \\
\begin{array}{c}0.850 \\
(0.357)\end{array}\end{array}$ & $\begin{array}{c}\text { Amount } \\
2396 \\
(2778)\end{array}$ \\
\hline High school dropout & 484 & $\begin{array}{c}0.978 \\
(0.146)\end{array}$ & $\begin{array}{c}3651 \\
(2821)\end{array}$ & $\begin{array}{c}0.493 \\
(0.500)\end{array}$ & $\begin{array}{l}403 \\
(733)\end{array}$ & $\begin{array}{c}0.978 \\
(0.146)\end{array}$ & $\begin{array}{c}4054 \\
(3259)\end{array}$ \\
\hline High school graduate & 763 & $\begin{array}{c}0.933 \\
(0.249)\end{array}$ & $\begin{array}{l}2835 \\
(2445)\end{array}$ & $\begin{array}{c}0.361 \\
(0.481)\end{array}$ & $\begin{array}{l}326 \\
(651)\end{array}$ & $\begin{array}{c}0.978 \\
(0.249)\end{array}$ & $\begin{array}{l}3161 \\
(2870)\end{array}$ \\
\hline Some post-high school & 2835 & $\begin{array}{c}0.884 \\
(0.320)\end{array}$ & $\begin{array}{c}2199 \\
(2369)\end{array}$ & $\begin{array}{c}0.294 \\
(0.456)\end{array}$ & $\begin{array}{c}211 \\
(527)\end{array}$ & $\begin{array}{c}0.884 \\
(0.320)\end{array}$ & $\begin{array}{c}2411 \\
(2710)\end{array}$ \\
\hline University degree & 1052 & $\begin{array}{c}0.672 \\
(0.470)\end{array}$ & $\begin{array}{c}1103 \\
(1756)\end{array}$ & $\begin{array}{c}0.146 \\
(0.353)\end{array}$ & $\begin{array}{c}106 \\
(423)\end{array}$ & $\begin{array}{c}0.672 \\
(0.470)\end{array}$ & $\begin{array}{c}1209 \\
(2033)\end{array}$ \\
\hline
\end{tabular}

Notes: Data come from the 2004 SLID.The table shows the proportion of observatios with child benefits greater than zero and the average child benefits (including those with zero). This is repeated for federal benefits, provincial benefits, and total benefits. Beneath each mean is the standard deviation in parentheses. Each row represents a different sample. 


\section{Table 2: First stage results in the SLID}

\begin{tabular}{|c|c|c|c|c|}
\hline & Nobs. & $(1)$ & (2) & (3) \\
\hline $\begin{array}{l}\text { Type of variation } \\
\text { in policy varible }\end{array}$ & & $\begin{array}{l}\text { Province- } \\
\text { year }\end{array}$ & $\begin{array}{l}\text { Province- } \\
\text { year-number } \\
\text { children }\end{array}$ & $\begin{array}{c}\text { Province- } \\
\text { year-number } \\
\text { children, } \\
\text { net measure }\end{array}$ \\
\hline All kids age $0-17$ & 85396 & $\begin{array}{c}941 \\
(104)\end{array}$ & $\begin{array}{c}905 \\
(105)\end{array}$ & $\begin{array}{c}884 \\
(102)\end{array}$ \\
\hline Just kids age $0-10$ & 55959 & $\begin{array}{l}1354 \\
(141)\end{array}$ & $\begin{array}{c}979 \\
(135)\end{array}$ & $\begin{array}{l}966 \\
(131)\end{array}$ \\
\hline $\begin{array}{l}\text { Kids age } 0-10 \\
\text { Just highs chool or less }\end{array}$ & 17704 & $\begin{array}{l}980 \\
(260)\end{array}$ & $\begin{array}{l}860 \\
(177)\end{array}$ & $\begin{array}{l}868 \\
(179)\end{array}$ \\
\hline $\begin{array}{l}\text { Kids age } 0-10 \\
\text { Two parent }\end{array}$ & 45958 & $\begin{array}{l}1373 \\
(169)\end{array}$ & $\begin{array}{l}906 \\
(140)\end{array}$ & $\begin{array}{c}889 \\
(136)\end{array}$ \\
\hline $\begin{array}{l}\text { Kids age } 0-10 \\
\text { Single }\end{array}$ & 10001 & $\begin{array}{l}1481 \\
(559)\end{array}$ & $\begin{array}{l}1947 \\
(168)\end{array}$ & $\begin{array}{l}1925 \\
(159)\end{array}$ \\
\hline
\end{tabular}

Notes: Regressions using the Survey of Labour and Income Dynamics. Regressors include year dummies, province dummies, respondent and spouse age group dummies, respondent and spouse education group dummies, age of youngest child dummies, and a marital status indicator. The second and third columns also include interaction terms for province*year, year*number of children, and province* number of children. 


\section{Table 3: Educational Outcomes}

\begin{tabular}{|c|c|c|c|c|c|c|c|}
\hline & \multicolumn{4}{|c|}{ All Education groups sample } & \multicolumn{3}{|c|}{$\begin{array}{c}\text { Regression coefficients } \\
\text { High School or Less sample }\end{array}$} \\
\hline & $\begin{array}{c}\text { Number of } \\
\text { Observations }\end{array}$ & $\begin{array}{c}\text { Age } \\
\text { Range }\end{array}$ & $\begin{array}{c}\text { Mean } \\
\text { (Std. Dev.) } \\
\end{array}$ & $\begin{array}{c}\text { Regression } \\
\text { coefficient }\end{array}$ & $\begin{array}{l}\text { Both } \\
\text { Sexes }\end{array}$ & $\begin{array}{l}\text { Just } \\
\text { boys }\end{array}$ & $\begin{array}{l}\text { Just } \\
\text { girls }\end{array}$ \\
\hline Child has ever repeated a grade & 40093 & $4-10$ & $\begin{array}{c}0.029 \\
{[0.169]}\end{array}$ & $\begin{array}{c}0.013 \\
{[0.005]^{*}}\end{array}$ & $\begin{array}{l}-0.005 \\
{[0.007]}\end{array}$ & $\begin{array}{l}-0.011 \\
{[0.010]}\end{array}$ & $\begin{array}{c}0.001 \\
{[0.007]}\end{array}$ \\
\hline Scaled math score & 17766 & $6-10$ & $\begin{array}{l}387.15 \\
{[89.27]}\end{array}$ & $\begin{array}{c}0.021 \\
{[0.019]}\end{array}$ & $\begin{array}{c}0.074 \\
{[0.042]^{*}}\end{array}$ & $\begin{array}{c}0.196 \\
{[0.073]^{* *}}\end{array}$ & $\begin{array}{l}-0.004 \\
{[0.040]}\end{array}$ \\
\hline Scaled PPVT score & 31407 & 4-6 & $\begin{array}{l}99.90 \\
{[15.35]}\end{array}$ & $\begin{array}{c}0.015 \\
{[0.026]}\end{array}$ & $\begin{array}{c}0.068 \\
{[0.041]^{*}}\end{array}$ & $\begin{array}{c}0.166 \\
{[0.061]^{* *}}\end{array}$ & $\begin{array}{l}-0.037 \\
{[0.060]}\end{array}$ \\
\hline $\begin{array}{l}\text { NOT been diagnosed with } \\
\text { learning disability }\end{array}$ & 55899 & $6-10$ & $\begin{array}{c}0.969 \\
{[0.173]}\end{array}$ & $\begin{array}{c}0.004 \\
{[0.004]}\end{array}$ & $\begin{array}{c}0.015 \\
{[0.004]^{* *}}\end{array}$ & $\begin{array}{c}0.023 \\
{[0.009]^{* *}}\end{array}$ & $\begin{array}{c}0.006 \\
{[0.006]}\end{array}$ \\
\hline
\end{tabular}


Table 4: Mental and Emotional Wellbeing Outcomes

\begin{tabular}{|c|c|c|c|c|c|c|c|}
\hline & \multicolumn{4}{|c|}{ All Education groups sample } & \multicolumn{3}{|c|}{$\begin{array}{c}\text { Regression coefficients } \\
\text { High School or Les s sample }\end{array}$} \\
\hline $\begin{array}{r}\mathrm{N} \\
\mathrm{Ob}\end{array}$ & $\begin{array}{l}\text { umber of } \\
\text { ervations }\end{array}$ & $\begin{array}{c}\text { Age } \\
\text { Range }\end{array}$ & $\begin{array}{c}\text { Mean } \\
\text { (Std. Dev.) } \\
\end{array}$ & $\begin{array}{c}\text { Regression } \\
\text { coefficient }\end{array}$ & $\begin{array}{l}\text { Both } \\
\text { Sexes } \\
\end{array}$ & $\begin{array}{c}\text { Just } \\
\text { boys } \\
\end{array}$ & $\begin{array}{l}\text { Just } \\
\text { girls } \\
\end{array}$ \\
\hline Hyperactivity-inattention score, 4- & 62671 & $4-10$ & $\begin{array}{c}4.364 \\
{[3.373]}\end{array}$ & $\begin{array}{c}-0.030 \\
{[0.014] *}\end{array}$ & $\begin{array}{c}-0.044 \\
{[0.029]}\end{array}$ & $\begin{array}{c}-0.042 \\
{[0.047]}\end{array}$ & $\begin{array}{c}-0.041 \\
{[0.044]}\end{array}$ \\
\hline Prosocial behaviour score - 4-11 & 44977 & $4-10$ & $\begin{array}{r}13.068 \\
{[3.887]}\end{array}$ & $\begin{array}{c}-0.028 \\
{[0.025]}\end{array}$ & $\begin{array}{c}-0.082 \\
{[0.048]^{*}}\end{array}$ & $\begin{array}{c}-0.051 \\
{[0.061]}\end{array}$ & $\begin{array}{c}-0.104 \\
{[0.055]^{*}}\end{array}$ \\
\hline Emotional dis order - Anxiety score & 62758 & $4-10$ & $\begin{array}{c}2.426 \\
{[2.411]}\end{array}$ & $\begin{array}{c}-0.043 \\
{[0.026]}\end{array}$ & $\begin{array}{c}-0.028 \\
{[0.029]}\end{array}$ & $\begin{array}{c}-0.011 \\
{[0.045]}\end{array}$ & $\begin{array}{c}-0.048 \\
{[0.039]}\end{array}$ \\
\hline Conduct dis order - physical aggres & 62732 & $4-10$ & $\begin{array}{c}1.421 \\
{[1.868]}\end{array}$ & $\begin{array}{c}-0.051 \\
{[0.019]^{* *}}\end{array}$ & $\begin{array}{c}-0.052 \\
{[0.028]^{*}}\end{array}$ & $\begin{array}{c}-0.018 \\
{[0.038]}\end{array}$ & $\begin{array}{c}-0.114 \\
{[0.037]^{* *}}\end{array}$ \\
\hline Indirect aggression score & 60238 & $4-10$ & $\begin{array}{c}0.994 \\
{[1.562]}\end{array}$ & $\begin{array}{c}-0.003 \\
{[0.016]}\end{array}$ & $\begin{array}{c}-0.045 \\
{[0.032]}\end{array}$ & $\begin{array}{c}-0.003 \\
{[0.033]}\end{array}$ & $\begin{array}{c}-0.100 \\
{[0.055]^{*}}\end{array}$ \\
\hline Mother's Depression Score & 103722 & $0-10$ & $\begin{array}{c}4.568 \\
{[5.348]}\end{array}$ & $\begin{array}{c}-0.043 \\
{[0.014]^{* *}}\end{array}$ & $\begin{array}{c}-0.116 \\
{[0.023]^{* *}}\end{array}$ & $\begin{array}{c}-0.073 \\
{[0.034]^{*}}\end{array}$ & $\begin{array}{c}-0.150 \\
{[0.032]^{* *}}\end{array}$ \\
\hline
\end{tabular}

Notes: Data is the NLSCY.Table shows the number of observations, age range, mean, and standard deviation for each dependent variable in the first three columns. The last four columns report coefficients on simula ted benefits for a

regression with the indicated variable as the dependent variable. Regressions include full set of control variables indicated in text. Standard errors a re reported beneath the estimates, with one sta for results significant at the 10 percent level and two stars for those significant at the 1 percent level of significance. 


\section{Table 5: Health and Nutrition Outcomes}

\begin{tabular}{|c|c|c|c|c|c|c|c|}
\hline & \multicolumn{4}{|c|}{ All Education groups sample } & \multicolumn{3}{|c|}{$\begin{array}{c}\text { Regression coefficients } \\
\text { High School or Less sample }\end{array}$} \\
\hline $\begin{array}{r}\mathrm{Ni} \\
\mathrm{Obs}\end{array}$ & $\begin{array}{l}\text { umber of } \\
\text { ervations }\end{array}$ & $\begin{array}{c}\text { Age } \\
\text { Range }\end{array}$ & $\begin{array}{c}\text { Mean } \\
\text { (Std. Dev.) } \\
\end{array}$ & $\begin{array}{c}\text { Regression } \\
\text { coefficient }\end{array}$ & $\begin{array}{l}\text { Both } \\
\text { Sexes } \\
\end{array}$ & $\begin{array}{c}\text { Just } \\
\text { boys } \\
\end{array}$ & $\begin{array}{l}\text { Just } \\
\text { girls }\end{array}$ \\
\hline Never experienced hunger becaus $\epsilon$ & 87072 & $2-10$ & $\begin{array}{c}0.987 \\
{[0.111]}\end{array}$ & $\begin{array}{c}0.001 \\
{[0.002]}\end{array}$ & $\begin{array}{c}0.011 \\
{[0.004]^{* *}}\end{array}$ & $\begin{array}{c}0.022 \\
{[0.007]^{* *}}\end{array}$ & $\begin{array}{c}0.002 \\
{[0.005]}\end{array}$ \\
\hline In general, child is in good/fair/por & 115910 & $0-10$ & $\begin{array}{c}0.118 \\
{[0.323]}\end{array}$ & $\begin{array}{c}0.003 \\
{[0.003]}\end{array}$ & $\begin{array}{c}0.006 \\
{[0.006]}\end{array}$ & $\begin{array}{c}0.020 \\
{[0.007]^{* *}}\end{array}$ & $\begin{array}{l}-0.011 \\
{[0.010]}\end{array}$ \\
\hline Current height in metres and centir & 96824 & $0-10$ & $\begin{array}{c}1.086 \\
{[0.245]}\end{array}$ & $\begin{array}{l}-0.004 \\
{[0.007]}\end{array}$ & $\begin{array}{c}0.023 \\
{[0.011]^{*}}\end{array}$ & $\begin{array}{c}0.051 \\
{[0.015]^{* *}}\end{array}$ & $\begin{array}{l}-0.008 \\
{[0.021]}\end{array}$ \\
\hline Current weight of child in kilogram & 108796 & $0-10$ & $\begin{array}{l}21.225 \\
{[9.752]}\end{array}$ & $\begin{array}{l}-0.008 \\
{[0.006]}\end{array}$ & $\begin{array}{l}-0.010 \\
0.0130\end{array}$ & $\begin{array}{l}-0.009 \\
{[0.025]}\end{array}$ & $\begin{array}{l}-0.011 \\
{[0.013]}\end{array}$ \\
\hline injured in last 12 months & 115855 & $0-10$ & $\begin{array}{c}0.094 \\
{[0.292]}\end{array}$ & $\begin{array}{c}0.005 \\
{[0.004]}\end{array}$ & $\begin{array}{c}0.000 \\
{[0.010]}\end{array}$ & $\begin{array}{c}-0.012 \\
{[0.013]}\end{array}$ & $\begin{array}{c}0.009 \\
{[0.011]}\end{array}$ \\
\hline Mother health status is excellent & 113803 & $0-10$ & $\begin{array}{c}0.354 \\
{[0.478]}\end{array}$ & $\begin{array}{c}0.008 \\
{[0.008]}\end{array}$ & $\begin{array}{c}0.003 \\
{[0.011]}\end{array}$ & $\begin{array}{c}0.015 \\
{[0.017]}\end{array}$ & $\begin{array}{c}-0.004 \\
{[0.011]}\end{array}$ \\
\hline
\end{tabular}

Notes: Data is the NLSCY.Table shows the number of observations, age range, mean, and standard deviation for each dependent variable in the first three columns. The last four columns report coefficients on simulated benefits for a

regression with the indicated variable as the dependent variable. Regressions include full set of control variables indicated in text. Standard errors a re reported beneath the estimates, with one star for results significant at the 10 percent level and two stars for those significant at the 1 percent level of significance. 


\section{Table 6: Persistence of effects}

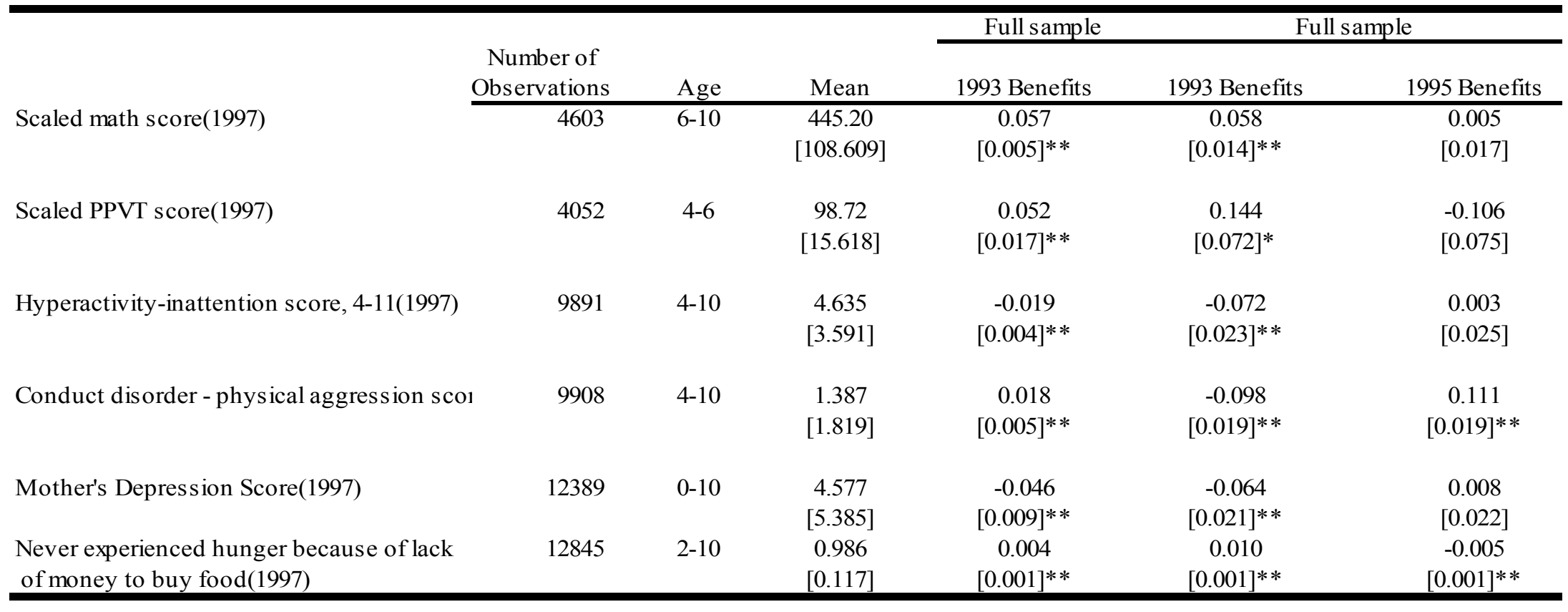

Notes: Data is the NLSCY.Table shows the number of observations, age range, mean, and standard deviation for each dependent variable in the first three columns. The next column shows the results from regressions using the 1997 value of the dependent variable and the 1993 benefit measure. The last two columns show the results from a regression using the 1997 dependent variable and both the 1993 and 1995 benefit measure in the same specification. Regressions include full set of control variables indicated in text. Standard errors are reported beneath the estimates, with one star for results significant at the 10 percent level and two starts for those significant at the 1 percent level of significance. 


\section{Table 7: Robustness Checks}

\begin{tabular}{|c|c|c|c|}
\hline & \multicolumn{2}{|c|}{ High School or Less } & \multirow{2}{*}{$\begin{array}{c}\text { University graduates } \\
\text { Reduced } \\
\text { form } \\
\end{array}$} \\
\hline & $\begin{array}{c}\text { Reduced } \\
\text { form }\end{array}$ & IV & \\
\hline Reported Child Benefits & -- & $\begin{array}{c}327 \\
{[116]^{* *}}\end{array}$ & -- \\
\hline Child has ever repeated a grade & $\begin{array}{l}-0.005 \\
{[0.007]}\end{array}$ & $\begin{array}{c}-0.055 \\
{[0.025]^{*}}\end{array}$ & $\begin{array}{c}0.012 \\
{[0.008]}\end{array}$ \\
\hline Scaled math score & $\begin{array}{c}0.074 \\
{[0.042]^{*}}\end{array}$ & $\begin{array}{c}0.458 \\
{[0.348]}\end{array}$ & $\begin{array}{c}-0.071 \\
{[0.036]^{*}}\end{array}$ \\
\hline Scaled PPVT score & $\begin{array}{l}0.068^{*} \\
{[0.041]}\end{array}$ & $\begin{array}{c}-0.416 \\
{[0.559]}\end{array}$ & $\begin{array}{c}0.008 \\
{[0.055]}\end{array}$ \\
\hline NOT been diagnosed with learning disability & $\begin{array}{c}0.015 \\
{[0.004]^{* *}}\end{array}$ & $\begin{array}{c}0.071 \\
{[0.026]^{* *}}\end{array}$ & $\begin{array}{c}0.014 \\
{[0.010]}\end{array}$ \\
\hline Hyperactivity-inattention score, $4-11$ & $\begin{array}{c}-0.044 \\
{[0.029]}\end{array}$ & $\begin{array}{c}0.105 \\
{[0.190]}\end{array}$ & $\begin{array}{c}-0.072 \\
{[0.034]^{*}}\end{array}$ \\
\hline Prosocial behaviour score - 4-11 & $\begin{array}{c}-0.082 \\
{[0.048]^{*}}\end{array}$ & $\begin{array}{c}-0.162 \\
{[0.107]}\end{array}$ & $\begin{array}{c}-0.016 \\
{[0.036]}\end{array}$ \\
\hline Emotional disorder - Anxiety score, 4-11 & $\begin{array}{c}-0.028 \\
{[0.029]}\end{array}$ & $\begin{array}{c}-0.088 \\
{[0.110]}\end{array}$ & $\begin{array}{c}-0.033 \\
{[0.042]}\end{array}$ \\
\hline Conduct disorder - physical aggression score & $\begin{array}{c}-0.052 \\
{[0.028]^{*}}\end{array}$ & $\begin{array}{c}0.044 \\
{[0.122]}\end{array}$ & $\begin{array}{c}-0.054 \\
{[0.044]}\end{array}$ \\
\hline Indirect aggression score & $\begin{array}{c}-0.045 \\
{[0.032]}\end{array}$ & $\begin{array}{c}0.273 \\
{[0.221]}\end{array}$ & $\begin{array}{c}0.039 \\
{[0.050]}\end{array}$ \\
\hline Mother's Depression Score & $\begin{array}{c}-0.116 \\
{[0.023]^{* *}}\end{array}$ & $\begin{array}{c}-0.600 \\
{[0.409]}\end{array}$ & $\begin{array}{c}-0.047 \\
{[0.021]^{*}}\end{array}$ \\
\hline $\begin{array}{l}\text { Never experienced hunger because of lack of money } \\
\text { to buy food. }\end{array}$ & $\begin{array}{c}0.011 \\
{[0.004]^{* *}}\end{array}$ & $\begin{array}{c}0.031 \\
{[0.014]^{*}}\end{array}$ & $\begin{array}{c}-0.006 \\
{[0.004]}\end{array}$ \\
\hline In general, child is in good/fair/poor health & $\begin{array}{c}0.006 \\
{[0.006]}\end{array}$ & $\begin{array}{c}0.080 \\
{[0.036]^{*}}\end{array}$ & $\begin{array}{l}-0.001 \\
{[0.026]}\end{array}$ \\
\hline Current height in metres and centimetres & $\begin{array}{c}0.023 \\
{[0.011]^{*}}\end{array}$ & $\begin{array}{c}0.138 \\
{[0.052]^{* *}}\end{array}$ & $\begin{array}{c}0.036 \\
{[0.040]}\end{array}$ \\
\hline Current weight of child in kilograms. & $\begin{array}{l}-0.010 \\
0.0130\end{array}$ & $\begin{array}{c}-0.124 \\
{[0.069]^{*}}\end{array}$ & $\begin{array}{c}0.004 \\
{[0.027]}\end{array}$ \\
\hline injured in last 12 months & $\begin{array}{c}0.000 \\
{[0.010]}\end{array}$ & $\begin{array}{l}-0.058 \\
{[0.050]}\end{array}$ & $\begin{array}{c}-0.030 \\
{[0.024]}\end{array}$ \\
\hline Mother health status is excellent & $\begin{array}{c}0.003 \\
{[0.011]}\end{array}$ & $\begin{array}{c}0.004 \\
{[0.032]}\end{array}$ & $\begin{array}{c}0.068 \\
{[0.027]^{*}} \\
\end{array}$ \\
\hline
\end{tabular}

Notes: Data is the NLSCY.The table shows in the frst two columns regression coefficients for reduced form and instrumental variables using the less than high school sample. The third column repeats the analysis for the university graduate sample. Regressions include full set of control variables indicated in text. Standard errors are reported beneath the estimates, with one star for results significant at the 10 percent level and two stars for those significant at the 1 percent level of significance. 
Figure 1: Policy differences across province, time, and family size

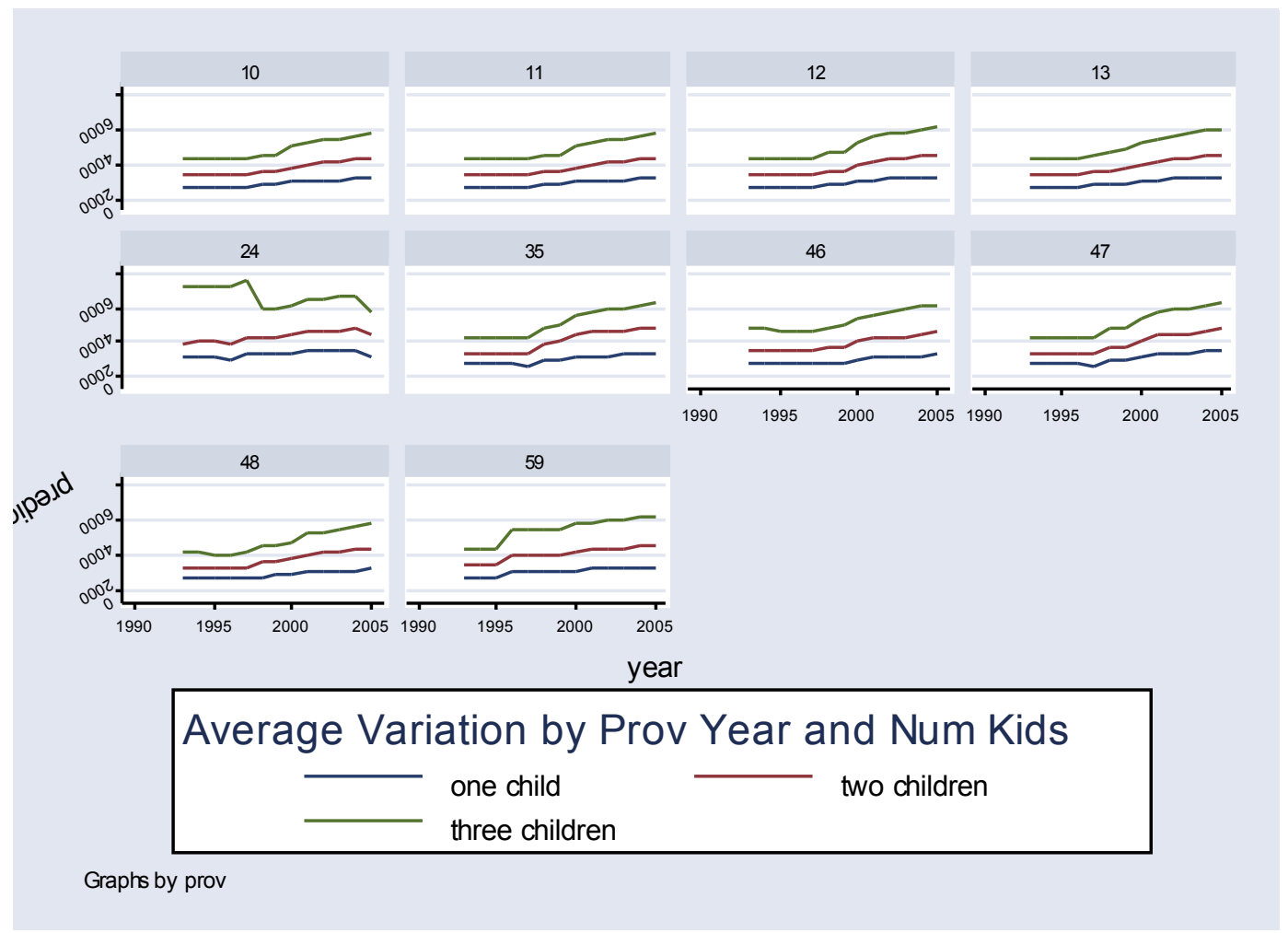




\section{Appendix A: National Child Benefit and Provincial Programs}

\section{Federal:}

The National Child Benefit Supplement began in 1998. The rates for 2005-06 were \$1,722 annually for a first child, $\$ 1,502$ for the second, and $\$ 1,420$ for a third child. These rates are approximately triple what was in place in 1998. The family income threshold for the clawback of these benefits in 2005 was $\$ 21,480$. The clawback rates were $12.2 \%$ for one child families, $22.8 \%$ for two child families, and $32.9 \%$ for three or more child families.

Unless otherwise mentioned, the provincial benefits described below were administered by the Canada Revenue Agency and integrated in one monthly payment with the federal CCTB and NCBS.

Several provinces reduced provincial social assistance payments dollar for dollar with the NCBS payments. Other provinces adjusted their social assistance payment schedule. These details are noted for each province below.

Newfoundland and Labrador:

The Newfoundland Child Benefit was introduced in 1999. In 2005, the annual rate for a first child was $\$ 250, \$ 326$ for a second child, $\$ 350$ for a third child, and $\$ 375$ for a fourth child. The clawback of these benefits was in the income range $\$ 17,397$ to $\$ 21,480$. An additional supplement for children age zero was added in 2001. This paid $\$ 540$ annually in 2005.

Social assistance payments were not clawed back, but the adjustment for family size in social assistance payments was changed in 1999 when the Newfoundland Child benefit was introduced..

Prince Edward Island:

No child benefit program. Full reduction of NCBS payment on provincial social assistance payments.

\section{Nova Scotia:}

The Nova Scotia Child Benefit started in 1998. Families with 1 to 3 children receive different payments. Initially in 1998, the payments ranged from $\$ 250$ for the first child to $\$ 136$ for a third (or higher) child. In 2001, the payments for third and higher children increased substantially. In 2005 , the payment rates were $\$ 445$ annually for a first child, $\$ 645$ for a second, and $\$ 720$ for a third. These benefits are clawed back at high clawback rates for incomes over $\$ 16,000$.

Full reduction of social assistance payments until 2001. After 2001, the social assistance payment structure for family size was adjusted instead. 
New Brunswick:

The New Brunswick Child Tax Benefit was introduced in 1997, before the national NCB program reached its start. The benefit is $\$ 250$ per child annually, and has not changed since 1997. The benefit is clawed back at $2.5 \%$ or $5 \%$ for family net income over $\$ 20,000$. In addition, there is a Working Income Supplement of \$250 annually that is phased in at 4\% for earned income over $\$ 3,750$ and clawed back at a rate of 5\% for family net income over $\$ 20,921$.

New Brunswick never reduced social assistance payments.

Quebec:

Until 1997, residents of Quebec were eligible for a family allowance, an allowance for young children, and an allowance for newborn children. These amounts increased with the number of children in the family and did not depend on family income. In 1997, these were combined into a new family allowance. The rates for the new family allowance were $\$ 2,275$ per child for a single parent family and $\$ 975$ per child for a two-parent family. These amounts were clawed back starting at incomes of $\$ 15,332$ for singles and $\$ 21,825$ for two-parent families. However, the clawback only took benefits down to a minimum benefit level that was $\$ 80$ annually for one and two child families and $\$ 975$ for three child families. But, for those with family net incomes higher than $\$ 50,000$ these 'minimum' benefits were clawed back at a rate of 5\%. In Quebec there was also an earned income benefit called APPORT in place from 1988 to 2004. In 2004, this benefit was phased in for earnings over $\$ 1,200$ at a rate of $35 \%$ until an earnings level of $\$ 11,370$ (two-parent) or $\$ 7,790$ (one-parent), and then clawed back at $43 \%$ after that. At the peak benefit level the benefit amount was quite large, but take-up of this benefit was not high.

In 2005 a new Child Assistance program replaced the family allowance and a new Work Premium replaced APPORT.

There was no reduction in social assistance payments for NCBS income, but social assistance and other child benefits were reformed in 1997.

\section{Ontario:}

Ontario introduced the Ontario Child Care Supplement for Working Parents in 1997. The initial rates were $\$ 400$ per child age 0 to 6 , clawed back at $4 \%$ for net family income over $\$ 20,000$. In 1998, the amounts were revamped and largely stayed the same until 2005. From 1998, the amount was phased in with earned income over $\$ 5000$, at a rate of $20 \%$ for 1998 and $21 \%$ from 1999 to 2005 . The 2005 benefit amount was $\$ 1,100$ per child age 0 to 6 for a one-parent family and $\$ 1310$ for a two-parent family. The clawback rate was $8 \%$ for incomes over $\$ 20,000$.

Full reduction of social assistance for NCBS payments until July 2004. From 2004, the increments to NCBS were protected from the reduction. 
Manitoba:

There was no new benefit specifically part of the NCB program in Manitoba, but a preexisting benefit called CRISP was in existence since the 1980s. It required a separate provincial application and social assistance recipients were not eligible. In 2005, CRISP paid $\$ 360$ annually per child, with a clawback rate of $2.083 \%$ for incomes over $\$ 12,384$. These amounts had not changed in nominal terms since the $1980 \mathrm{~s}$.

Full reduction of social assistance payments for NCBS benefits until 2001. From 2001, no reduction for children under age 7 . From 2003, no reduction for children under age 12.

\title{
Saskatchewan:
}

The Saskatchewan Child Benefit was introduced in 1998. In the first year, it paid $\$ 900$ annually to a one child family, $\$ 1,104$ for a second child, and $\$ 1,176$ for a third. As the NCBS increased in the following years, the Saskatchewan Child Benefit was decreased downward dollar for dollar, so that by 2005 it paid only $\$ 7$ annually for a 2 nd child and $\$ 86$ for a third. It is clawed back at high rates for family net incomes over $\$ 15,921$.

Additionally, there is a working income supplement in Saskatchewan. In 2005 the amount ranges from $\$ 2,385$ for a one child family to $\$ 4,293$ for a five child family. It is phased in for earnings over $\$ 1,500$ at rates between $25 \%$ and $45 \%$ and clawed back at a $20 \%$ rate for incomes over $\$ 14,640$. There is a supplement for children under age 13 that pays an extra $25 \%$ on top of the regular employment supplement.

There was no reduction in social assistance payments, but as noted above the Saskatchewan Child Benefit shrank dollar for dollar with NCBS increases through time.

\begin{abstract}
Alberta:
Alberta has an employment-related child benefit. It was introduced in 1997 with a phase-in rate of $8 \%$ for earnings over $\$ 6,500$ up to a maximum of $\$ 250$ for one child and $\$ 500$ for two or more. The benefit is clawed back at a rate of $4 \%$ for incomes over $\$ 25,000$.

Between 1998 and 2004, the benefit maximum was set at $\$ 500$ for one child and $\$ 1000$ for two ore more children, but was otherwise similar to 1997. The benefit changed again for the 2005 year.
\end{abstract}

There is full reduction of social assistance payments for the NCBS benefits.

British Columbia:

The BC Family Bonus was introduced in 1996, two years before the NCB program. The Bonus rate was $\$ 1,236$ per child and was clawed back at a rate of $8 \%$ for one child and $16 \%$ for two or more for incomes higher than $\$ 18,000$. These amounts were increased to $\$ 1,332,9 \%, 18 \%$, and $\$ 20,500$ in 2001 and have remained constant since. However, the NCBS is subtracted from the BC Family Bonus, rendering it to zero by 2005 since the NCBS is now larger than the prescribed BC Family Bonus payments. There is also a BC Earned Income Benefit that was introduced in 1998. It pays differing amounts for each child and is phased in between earnings levels of $\$ 3,750$ and $\$ 10,000$. It is clawed back for incomes higher than $\$ 20,921$ at high rates. The amounts for 2005 are $\$ 365$ for the first child, $\$ 370$ for the second, and $\$ 372$ for the third or higher. Until 2003, the amount for the first child was $\$ 605$, with $\$ 405$ for the second and $\$ 330$ for the third. 
There is no reduction of social assistance for the NCBS payments, but the NCBS payments reduced the BC Family Bonus as described above.

\section{Appendix B: Questionnaire extracts}

\section{Mental Health Variables}

1. Hyperactivity Score in Cycle 1 (1994). Variable ABECS06. Questions:

a) HOW OFTEN WOULD YOU SAY THAT \%FNAME\%: Can't sit still, is restless or hyperactive? b)HOW OFTEN WOULD YOU SAY THAT \%FNAME\%: Is distractible, has trouble sticking to any activity?

c)HOW OFTEN WOULD YOU SAY THAT \%FNAME\%: Fidgets?

d)HOW OFTEN WOULD YOU SAY THAT \%FNAME\%: Can't concentrate, can't pay attention for long?

e)HOW OFTEN WOULD YOU SAY THAT \%FNAME\%: Is impulsive, acts without thinking?

f) HOW OFTEN WOULD YOU SAY THAT \%FNAME\%: Has difficulty awaiting turn in games or groups?

g)HOW OFTEN WOULD YOU SAY THAT \%FNAME\%: Cannot settle to anything for more than a few

h) HOW OFTEN WOULD YOU SAY THAT \%FNAME\%: Is inattentive?

2. Emotional Disorder Score in Cycle 1 (1994). Variable ABECS08. Questions:

a)HOW OFTEN WOULD YOU SAY THAT \%FNAME\%: Seems to be unhappy, sad or depressed? b)HOW OFTEN WOULD YOU SAY THAT \%FNAME\%: Is not as happy as other children? c)HOW OFTEN WOULD YOU SAY THAT \%FNAME\%: Is worried?

d)HOW OFTEN WOULD YOU SAY THAT \%FNAME\%: Cries a lot?

e)HOW OFTEN WOULD YOU SAY THAT \%FNAME\%: Appears miserable, unhappy, tearful, or distressed?

f)HOW OFTEN WOULD YOU SAY THAT \%FNAME\%: Is nervous, highstrung or tense?

g)HOW OFTEN WOULD YOU SAY THAT \%FNAME\%: Has trouble enjoying \%him/her\%self?

h) HOW OFTEN WOULD YOU SAY THAT \%FNAME\%: Is too fearful or anxious?

3. Aggression Score in Cycle 1 (1994). Variable ABECS09. Questions:

a)HOW OFTEN WOULD YOU SAY THAT \%FNAME\%: Gets into many fights?

b)HOW OFTEN WOULD YOU SAY THAT \%FNAME\%: When another child accidentally hurts

$\%$ him $/$ her\% (such as by bumping into $\%$ him/her\%), assumes that the other child meant to do it, and then reacts with anger and fighting?

c)HOW OFTEN WOULD YOU SAY THAT \%FNAME\%: Physically attacks people?

d)HOW OFTEN WOULD YOU SAY THAT \%FNAME\%: Threatens people?

e)HOW OFTEN WOULD YOU SAY THAT \%FNAME\%: Is cruel, bullies or is mean to others?

f)HOW OFTEN WOULD YOU SAY THAT \%FNAME\%: Kicks, bites, hits other children?

\section{Prosocial Behvaiour Score in Cycle 1 (Variable:ABECS07) ages 4-11}

The total score varies from 0 to 20 , a high score indicating prosocial behavior

a) Using the answers never or not true, sometimes or somewhat true, or often or very true, how often would you say that $\%$ fname $\%$ : shows sympathy to someone who has made a mistake?

b) HOW OFTEN WOULD YOU SAY THAT \%FNAME\%: Will try to help someone who has been hurt?

c) HOW OFTEN WOULD YOU SAY THAT \%FNAME\%: Volunteers to help clear up a mess someone else has made?

d) HOW OFTEN WOULD YOU SAY THAT \%FNAME\%: If there is a quarrel or dispute, will try to stop it? 
e) HOW OFTEN WOULD YOU SAY THAT \%FNAME\%: Offers to help other children (friend, brother or sister) who are having difficulty with a task?

f) HOW OFTEN WOULD YOU SAY THAT \%FNAME\%: Comforts a child (friend, brother, or sister) who is crying or upset?

g) HOW OFTEN WOULD YOU SAY THAT \%FNAME\%: Spontaneously helps to pick up objects which another child has dropped (e.g. pencils, books, etc.)?

h) HOW OFTEN WOULD YOU SAY THAT \%FNAME\%: Will invite bystanders to join in a game?

i) HOW OFTEN WOULD YOU SAY THAT \%FNAME\%: Helps other children (friends, brother or sister) who are feeling sick?

j) HOW OFTEN WOULD YOU SAY THAT \%FNAME\%: Takes the opportunity to praise the work of less able children?

5. Indirect Aggression Score in Cycle 1 ages 4-11

The total score varies from 0 to 10 , a high score indicating behavior associated with indirect aggression.

a) HOW OFTEN WOULD YOU SAY THAT \%FNAME\%: When mad at someone, tries to get others to dislike that person?

b) HOW OFTEN WOULD YOU SAY THAT \%FNAME\%: When mad at someone, becomes friends with another as revenge?

c) HOW OFTEN WOULD YOU SAY THAT \%FNAME\%: When mad at someone, says bad things behind the other's back?

d) HOW OFTEN WOULD YOU SAY THAT \%FNAME\%: When mad at someone, says to others: let's not be with him/her?

e) HOW OFTEN WOULD YOU SAY THAT \%FNAME\%: When mad at someone, tells the other one's secrets to a third person?

\section{Adult Health Depression Score}

a) HOW OFTEN YOU HAVE FELT OR BEHAVED THIS WAY DURING THE PAST WEEK: I did not feel like eating; my appetite was poor.

1 RARELY OR NONE OF THE TIME (LESS THAN 1 DAY)

2 SOME OR A LITTLE OF THE TIME (1-2 DAYS)

3 OCCASIONALLY OR A MODERATE AMOUNT OF TIME (3-4 DAYS)

4 MOST OR ALL OF THE TIME (5-7 DAYS)

b) HOW OFTEN YOU HAVE FELT OR BEHAVED THIS WAY DURING THE PAST WEEK: I felt that I could not shake off the blues even with help from my family or friends.

c) HOW OFTEN YOU HAVE FELT OR BEHAVED THIS WAY DURING THE PAST WEEK: I had trouble keeping my mind on what I was doing.

d) HOW OFTEN YOU HAVE FELT OR BEHAVED THIS WAY DURING THE PAST WEEK: I felt depressed.

e)HOW OFTEN YOU HAVE FELT OR BEHAVED THIS WAY DURING THE PAST WEEK: I felt that everything I did was an effort.

f) HOW OFTEN YOU HAVE FELT OR BEHAVED THIS WAY DURING THE PAST WEEK: I felt hopeful about the future.

g) HOW OFTEN YOU HAVE FELT OR BEHAVED THIS WAY DURING THE PAST WEEK: My sleep was restless.

h)HOW OFTEN YOU HAVE FELT OR BEHAVED THIS WAY DURING THE PAST WEEK: I was happy. 
i)HOW OFTEN YOU HAVE FELT OR BEHAVED THIS WAY DURING THE PAST WEEK: I felt lonely.

FREQ WTD

j)HOW OFTEN YOU HAVE FELT OR BEHAVED THIS WAY DURING THE PAST WEEK: I enjoyed life.

k)HOW OFTEN YOU HAVE FELT OR BEHAVED THIS WAY DURING THE PAST WEEK: I had crying spells.

1) HOW OFTEN YOU HAVE FELT OR BEHAVED THIS WAY DURING THE PAST WEEK: I felt that people disliked me. 